\title{
Anphira guianensis sp. nov. (Isopoda, Cymothoidae) from the gills of Acnodon oligacanthus Eigenmann (Pisces, Serrasalmidae) of French Guiana ${ }^{1}$
}

\author{
Vernon E. Thatcher ${ }^{2}$
}

\begin{abstract}
Anphira guianensis sp. nov. (Isopoda, Cymothoidae) is described from the branchial cavity of a freshwater fish, Acnodon oligacanthus Eigenmann, 1903 from French Guiana. The new species differs from the other known species of the genus in a number of important respects. Adult females are less convex than those of the other two known species and the mouth points downward. The coxal plates are largest posteriorly, unlike those of the other species. The antennule is much stouter and longer than the antenna whereas in the other species these appendages are subequal. Additionally, the dactyls of the new species are much longer.

KEY WORDS. Cymothoidae, Isopod parasite, fish parasite, Brazil
\end{abstract}

TRILLES (1991) listed 334 species of cymothoids in 42 genera parasitizing fishes worldwide. THATCHER (2000) reported that 45 of these occur in South America. In Brazil, some 30 species are known including both marine and freshwater forms. The genus Anphira was proposed by THATCHER (1993) for a species called $A$. branchialis from the upper part of the branchial chamber of piranhas, Serrasalmidae. Later, the same author described a second species, A. xinguensis Thatcher, 1995, from another serrasalmid fish, Ossubtus xinguense Jégu, 1992, taken from the Xingu River of Amazonian Brazil. The present paper describes an additional species of Anphira from a serrasalmid fish of French Guiana. This would be the first report of this genus in that country.

\section{MATERIAL AND METHODS}

The Cymothoidae were removed from the branchial chambers of their hosts and preserved in $70 \%$ alcohol. Mouthparts and other appendages were removed with dissecting needles and cleared in pure phenol for study. Permanent preparations were made of some appendages utilizing the phenol-balsam method described in THATCHER (1991). Photographs were taken with a digital camera at 5000 pixels and drawings were made with the aid of a camera lucida. Measurements are in micrometers $(\mu \mathrm{m})$ unless designated as millimeters $(\mathrm{mm})$.

1) Contribution number 1403 of the Departamento de Zoologia, Universidade Federal do Paraná.

2) Departamento de Zoologia, Universidade Federal do Paraná. Caixa Postal 19020, 81531-980 Curitiba, Paraná, Brasil. Research Fellow of the CNPq. 


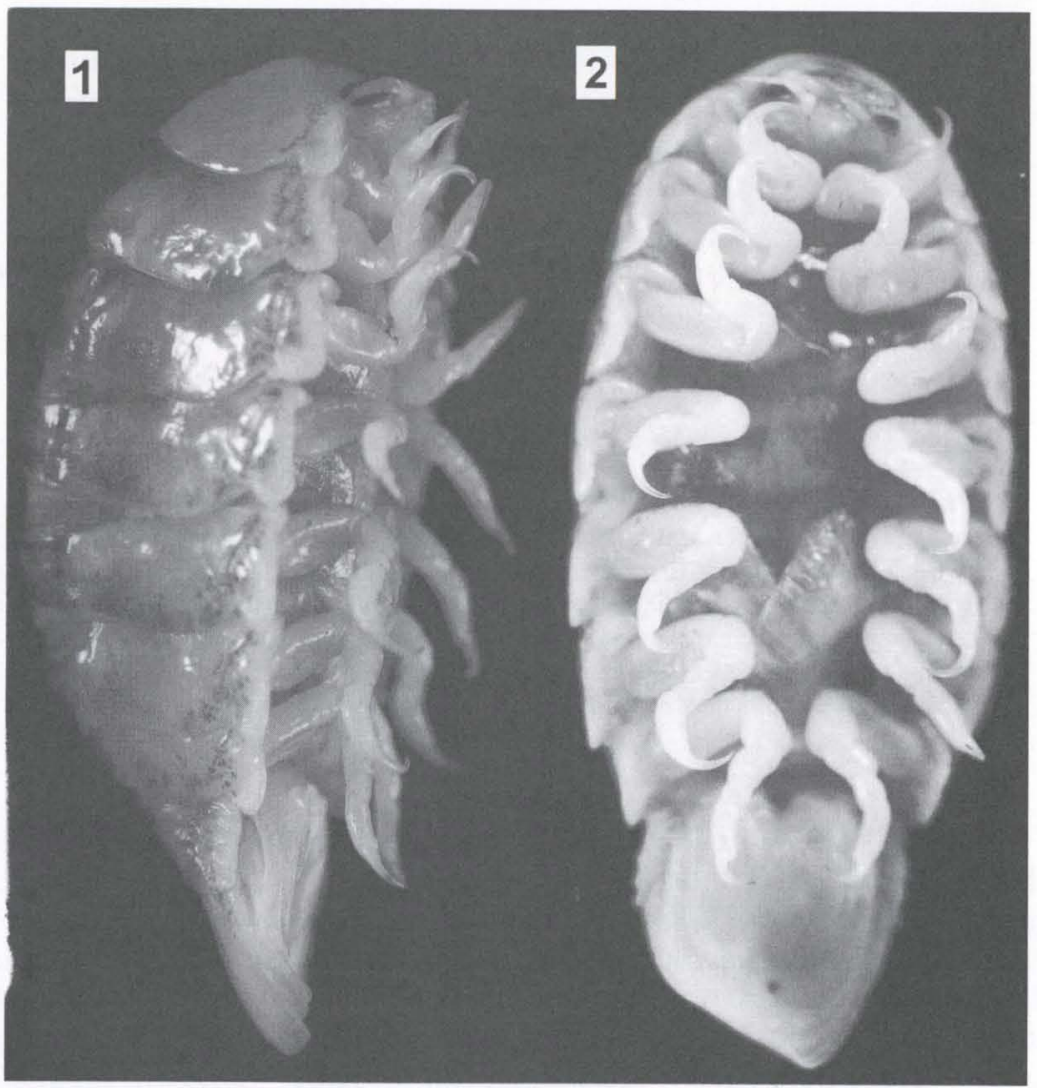

Figs 1-2. Anphira guianensis sp. nov., female: (1) lateral view; (2) ventral view. Scale $=2 \mathrm{~mm}$.

\section{RESULTS}

\section{Anphira guianensis sp. nov.}

Figs 1-24

Host: Acnodon oligacanthus Eigenmann, 1903, Serrasalmidae.

Site: branchial chambers.

Locality: Maroni River, French Guiana.

Intensity: 1-2 individuals per host fish.

Type material: Holotype female, Alotype male, 4 Paratype females and 2 Paratype males in the Crustacean Collection of the Instituto Nacional de Pesquisas da Amazônia, Manaus, Amazonas, Brazil (INPA 890-893).

Description (based on seven females and five males studied and measured; measurements in table I). Female (Figs 1-2): body 2 to 2.5 times longer than wide; nearly as high as wide; extensive dark brown pigmentation dorsally, white to cream laterally and ventrallly. Cephalon immersed in pereonite 1, depressed downward, 


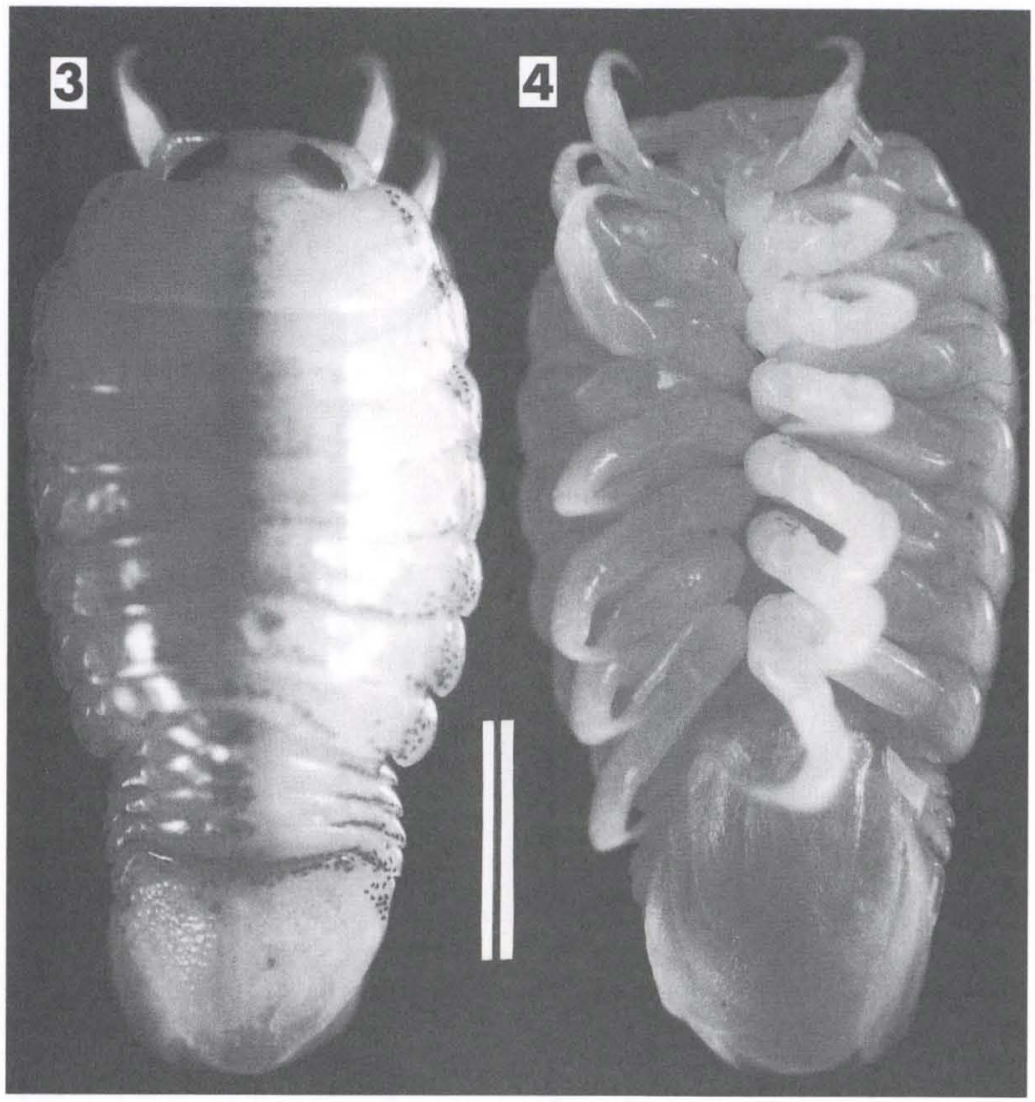

Figs 3-4. Anphira guianensis sp. nov., male: (3) dorsal view; (4) ventral view. Scale $=2 \mathrm{~mm}$.

Table I. Measurements (mm) of seven females and five males of Anphira guianensis sp. nov.

\begin{tabular}{|c|c|c|c|c|c|}
\hline & \multicolumn{3}{|c|}{ Body } & \multicolumn{2}{|c|}{ Pleotelson } \\
\hline & Length & Width & Depth & Length & Width \\
\hline \multirow[t]{7}{*}{ Females } & 20 & 9 & 9 & 7 & 6 \\
\hline & 15 & 6 & 6 & 3 & 4 \\
\hline & 14 & 6 & 5 & 3 & 3 \\
\hline & 14 & 6 & 4 & 4 & 4 \\
\hline & 12 & 5 & 4 & 2 & 3 \\
\hline & 12 & 6 & 5 & 3 & 3 \\
\hline & 12 & 6 & 5 & 2 & 3 \\
\hline \multicolumn{6}{|l|}{ Males } \\
\hline & 8 & 4 & 3 & 2 & 2 \\
\hline & 8 & 3 & 3 & 3 & 2 \\
\hline & 7 & 4 & 3 & 2 & 1 \\
\hline & 7 & 5 & 2 & 2 & 2 \\
\hline & 7 & 3 & 2 & 2 & 2 \\
\hline
\end{tabular}




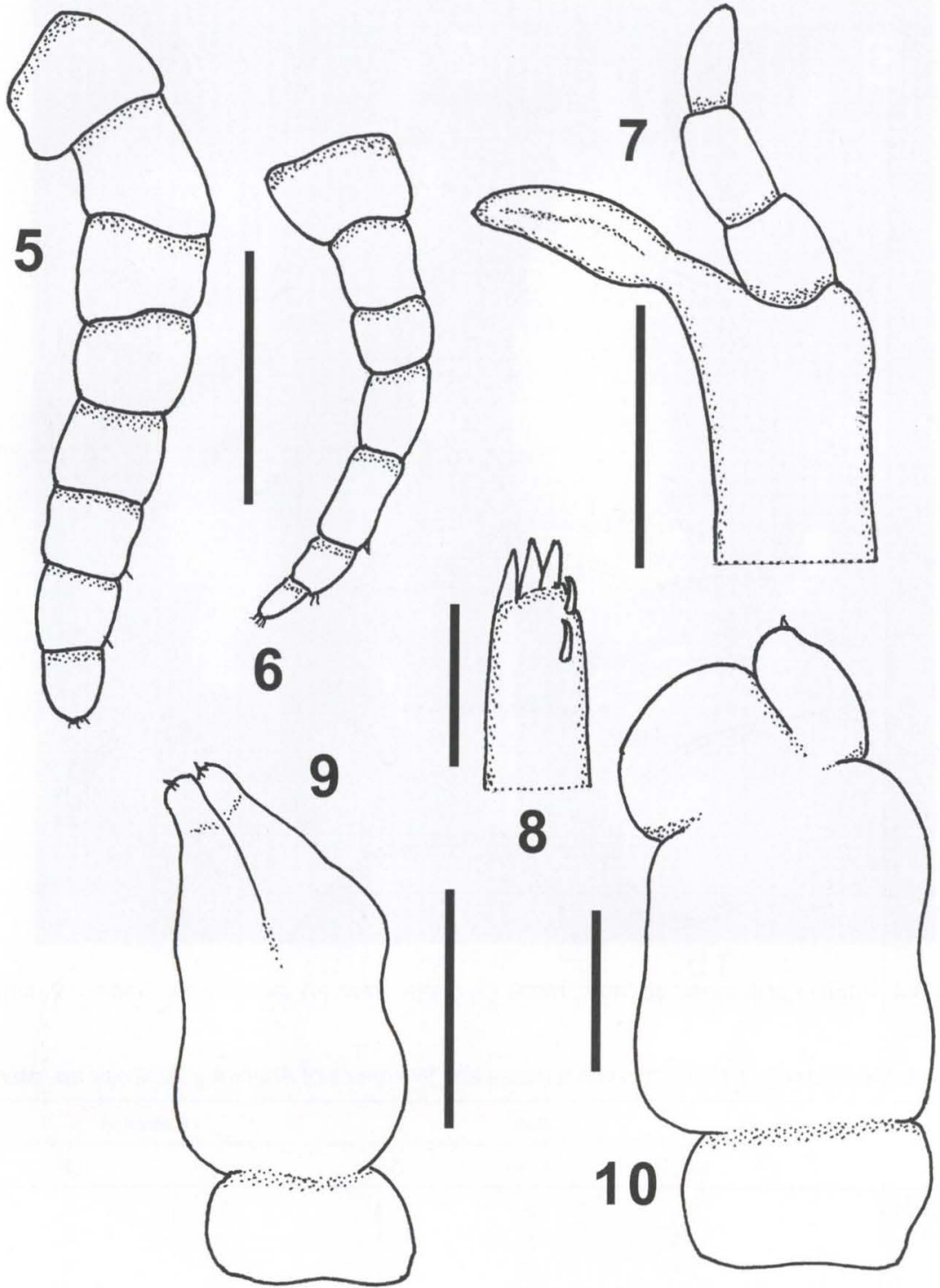

Figs 5-10. Anphira guianensis sp. nov., female: (5) antennule, (6) antenna. Scale for 5-6 = 1 $\mathrm{mm}$; (7) mandible and palp; (8) maxillule; (9) maxilla; (10) maxilliped. Scale for $8=25 \mu \mathrm{m}$, others $=500 \mu \mathrm{m}$.

mouth ventral, eyes prominent. Antennule stout, (Fig. 5) of 8 articles. Antenna (Fig. 6) slender and shorter, of 7 articles. Mouthparts (Figs 7-10): mandible flattened, lacking incisor; mandibular palp subequal in length to mandible: maxillule with 3 larger spines terminally and 2 smaller spines subterminally; maxilla bilobed with a 


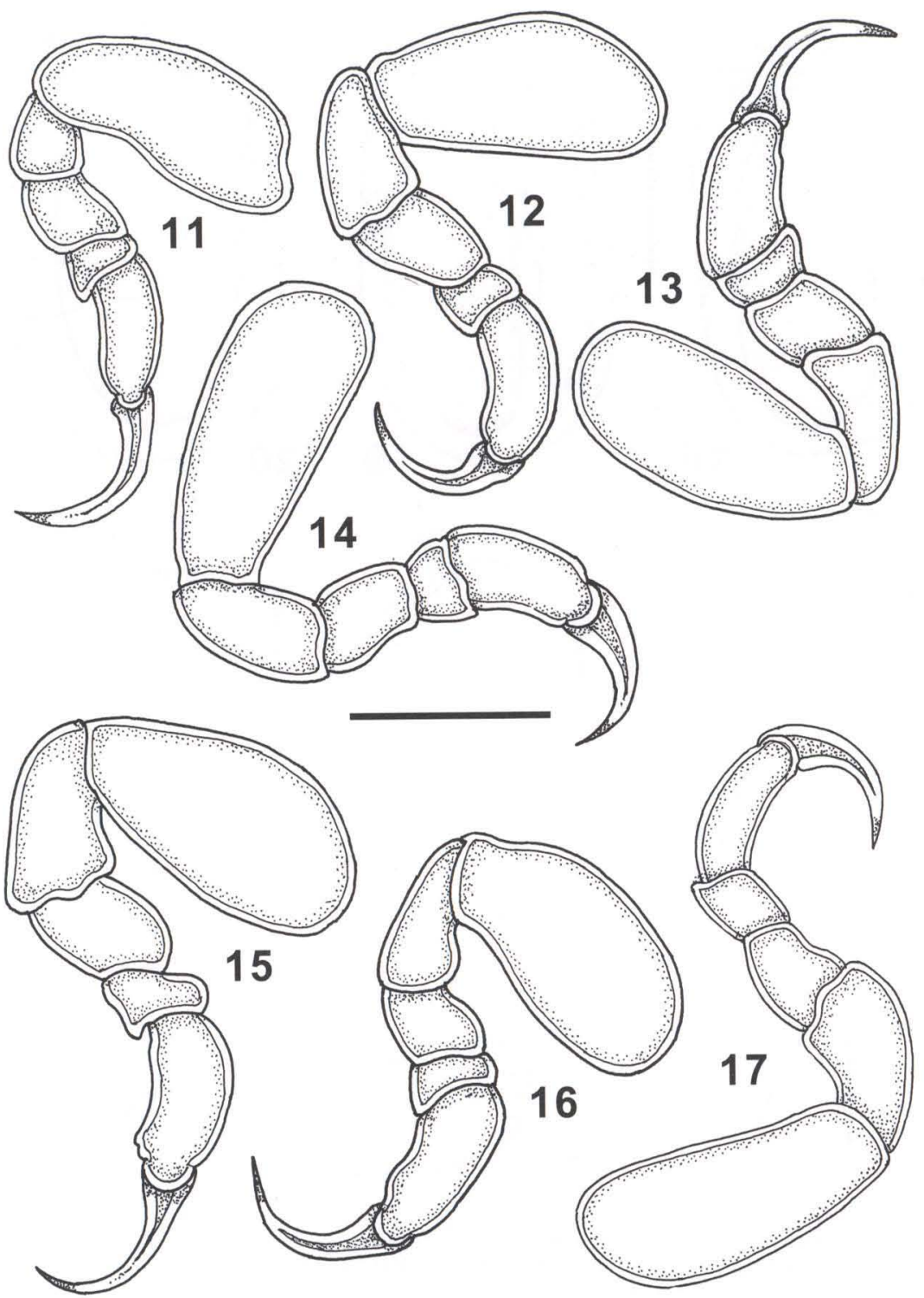

Figs 11-17. Anphira guianensis sp. nov., female: (11) pereopod 1; (12) pereopod 2; (13) pereopod 3; (14) pereopod 4; (15) pereopod 5; (16) pereopod 6; (17) pereopod 7 . Scale = 1 $\mathrm{mm}$.

recurved terminal spine on each lobe; maxilliped with palp bearing 1 or 2 spines terminally. Pereon moderately convex, highest at level of pereonite 3 ; pereonite 1 twice the length of 2-4; pereonites 5-7 become progressively shorter. Coxal plates free on all pereonites, become longer posteriorly. Pereopods (Figs 11-17) relatively 

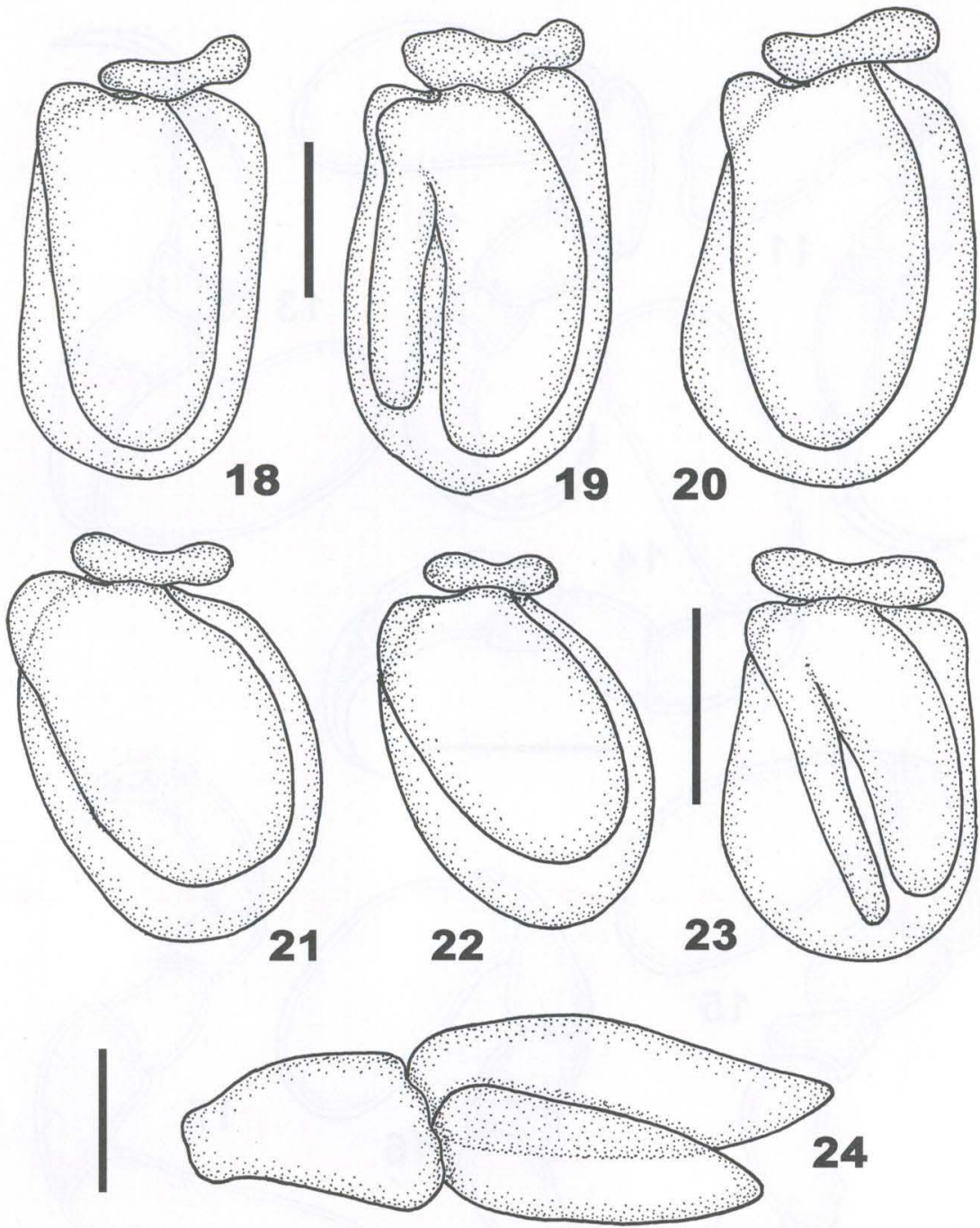

Figs 18-24. Anphira guianensis sp. nov. 18-22, female pleopods: (18) pleopod 1; (19) pleopod 2; (20) pleopod 1; (21) pleopod 4; (22) pleopod 5; (23) male pleopod 2; (24) female uropod. Scale for $24=500 \mu \mathrm{m}$, other two scales $=1 \mathrm{~mm}$.

long with elongate dactyls. Pleon immersed in pereonite 7; pleonites produced laterally; pleopods (Figs 18-22) simple, bilaminar, with appendix masculinum on second. Pleotelson simple, about as wide as long, not inflated dorsally. Uropod (Fig. 24) with both rami acute, exopod slightly longer than endopod.

Male (Figs 3, 4 and 23): Body smaller than that of female; 1.4-2.7 times longer than wide; less convex than female. Cephalon immersed in pereonite 1; eyes large; frons bluntly rounded; mouth ventral. Other characters similar to those of female. 


\section{DISCUSSION}

Anphira guianensis sp. nov. differs from the other two known species of the genus in the following respects. The coxal plates are larger posteriorly whereas the reverse is true in A. branchialis and in A. xinguensis they are subequal in size. The pereon is less convex in the new species and the mouth is ventral. The antennule of the new species is stouter and longer than the antenna while in the other two species these appendages are subequal in size. The dactyls of the new form are considerably longer than those of the other species.

ACKNOWLEDGMENT. The author thanks Dr. Michel Jégu of the Laboratoire d'Ichtyologie générale et appliquée, Muséum national d'Histoire naturelle, Paris, France, for collecting the specimens and making them available for study.

\section{REFERENCES}

Trilles, J.P. 1991. Catalogue mondial des Cymothoidae. Studia Marina, Kotor, 21/22(1-2): 5-288. ThatCher, V.E. 1991. Amazon fish parasites. Amazoniana, Plöen, 11(3/4): 263-571.

- 1993. Anphira branchialis gen. et sp. nov. (Crustacea, Isopoda, Cymothoidae) a gill cavity parasite of piranhas (Serrasalmus spp.) in the Brazilian Amazon. Acta Amazonica, Manaus, 23 (2-3): 297-307.

1995. Anphira xinguensis sp. nov. (Isopoda, Cymothoidae) a gill chamber parasite of an Amazonian serrasalmid fish, Ossubtus xinguense Jégu, 1992. Amazoniana, Plöen, 13(3/4): 293-303.

2000. The isopod parasites of South American fishes. p. 193-226. In: G. Salgado-Maldonado; A.N.G. Aldrete \& V.M. Vidal-Martinez (Eds). Metazoan parasites in the Neotropics: A systematic and ecological perspective. Mexico, Instituto de Biologia, Univ. Nacional Autónoma de México, 310p.

Received in 01.VIII.2002; accepted in 05.XI.2002. 